\title{
PCR Detection of Some ESBLs (bla) Genes in Pseudomonas aeruginosa Isolated from Burn's Units in Bagdad Hospitals

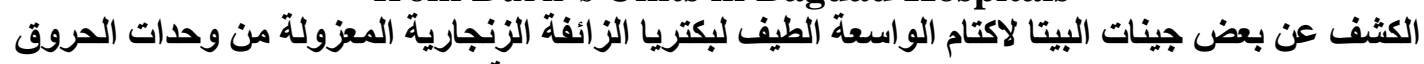

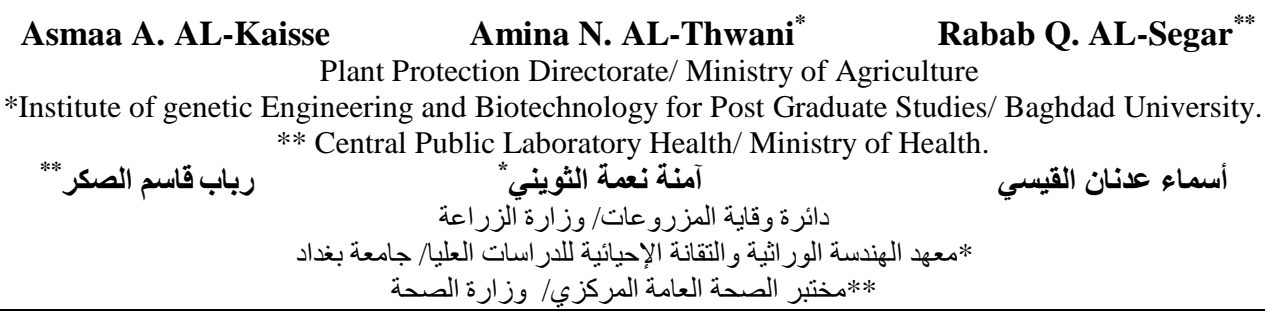

Amina N. AL-Thwani*

Plant Protection Directorate/ Ministry of Agriculture

*Institute of genetic Engineering and Biotechnology for Post Graduate Studies/ Baghdad University.

** Central Public Laboratory Health/ Ministry of Health.

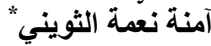

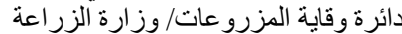

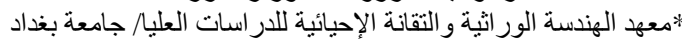

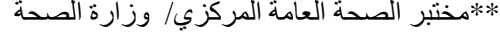

\begin{abstract}
Multi drug resistant (MDR) and Extended Spectrum Beta Lactamase (ESBLs) of Pseudomonas aeruginosa were detected. Pseudomonas aeruginosa is a bacterium responsible for severe infections in burn's units, plasmid DNA analysis and encoded many types of genes responsible for beta-lactamases. To determine the type of genes responsible for beta-lactam broad spectrum in $P$. aeruginosa strains isolated from 100 swabs of burn's units environment, using a molecular methods (PCR) by primers specific to ESBLs (bla) genes oxacillin hydrolyzing capabilities OXA-10, OXA-4 and Vietnam Extended-Spectrum $\beta$-Lactame VEB-1. The results revealed that 15 strains were isolated from burn units environment. All of $15(100 \%)$ were positive OXA-10 and only one (6.6\%) for OXA-4 while the other gene VEB-1 was found in $6(40 \%)$ isolates.
\end{abstract}

Key words: Burn's units, Pseudomonas aeruginosa, PCR, Resistance genes.

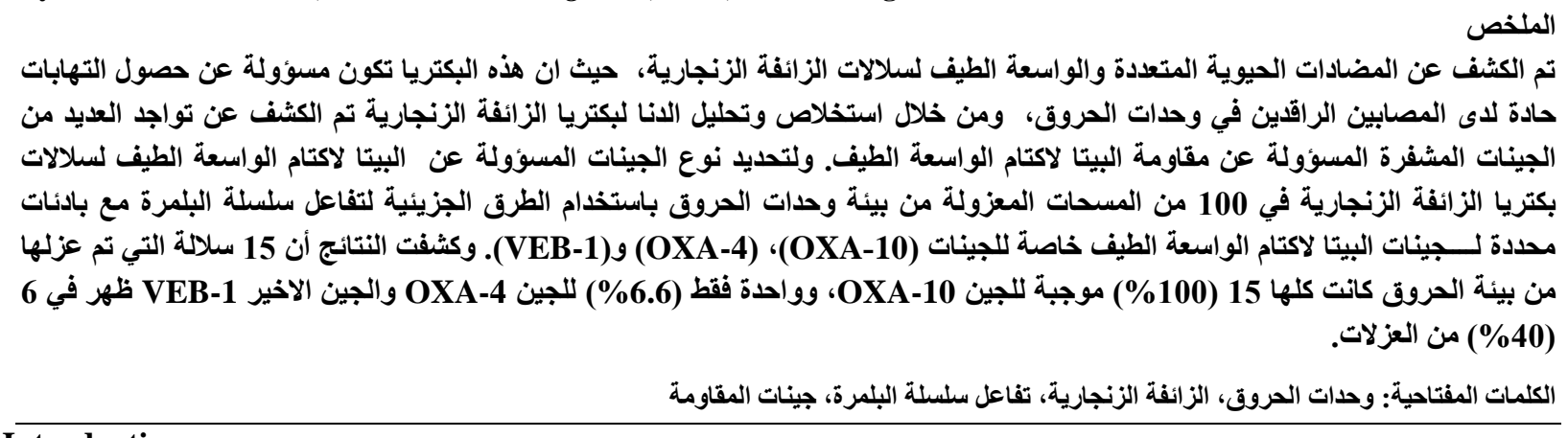

\section{Introduction}

Hospital environment is contaminate by a variety of pathogenic and nonpathogenic microorganisms that can persist on surfaces for prolonged periods, numerous studies showed that hospital surfaces and frequently used medical equipments become contaminated by a variety of these microorganisms. The acquisition of nosocomial pathogens by a patients and the resultant development of infection depend on a multifaceted interplay between the environment, a pathogen and a susceptible host [1]. Transmission can occur either indirectly when a healthcare worker's hands and/or gloves become contaminated by touching contaminated surfaces after which they touch patients, or when a patient comes in direct contact with a contaminated surface [2]. Antibiotic resistance in $P$. aeruginosa may be mediated via several distinct mechanisms including modification of site-targeted drugs or outer membranes, $\beta$-lactamase production, and efflux pumps. The increase in antibiotic resistance is mostly due to extensive abuse of antibiotics such as ciprofloxacin, $\beta$-lactamase and aminoglycosides in the burn centers as well as non-availability and high costs of other effective drugs [3]. Extended spectrum $\beta$ - lactamases (ESBLs) are a group of enzymes produced by some microorganisms with the ability to hydrolyse and cause resistance to the antimicrobial agents as Oxymino - Cephalosporins (i.e.Cefotaxime, Ceftazidime, Ceftriaxone, Cefuroxime and Cefepime) Monobactams (i.e. Aztreonam), whereas cannot hydrolyze Carbapenems (i.e. Imipenem) efficiently [4]. Generally, ESBLs are not carried on the bacterial chromosome, rather they are found on an independent element of DNA called a plasmid. Plasmids can carry many different genes on them and have the ability to transfer a replica of themselves to other bacteria. This can be very serious for a number of reasons [5]. The molecular classification of $b$ - lactamases is based on the nucleotide and amino acid sequences in these enzymes. To date, four classes are recognised (A-D), correlating with the functional classification. Classes A, C, and D act by a serine based mechanism, whereas class B or metallo b- lactamases need zinc for their action [6]. 
These enzyme are named OXA because they preferentially hydrolyze oxacillin and cloxacillin. These enzymes confer resistance to ceftazidime and are poorly inhibited by clavulanic acid [7]. The OXA-1 and OXA-4 enzymes are highly homologous: there are only two amino acid differences, with the OXA-4 enzyme having Aspartic acid 48 Valine and Aspartic acid 207 Glutamic acid substitutions relative to the OXA-1 sequence, OXA-4 $\beta$-lactamase is generally plasmid- mediated, the chromosomal DNA of these isolates, but not their plasmids, hybridized with the OXA-4 gene amplified by the PCR method [8]. OXA-10 $\beta$-lactamase also possesses the ability to hydrolyze Cephalosporins, hydrolyzing Cefotaxime, Ceftriaxone, and Aztreonam at low levels but sparing Ceftazidime, Cephamycins, and Carbapenems [9]. VEB-1 (for Vietnamese extended spectrum beta - lacctamase), VEB-1 has highest amino-acid identity with Pseudomonas Extended Resistance (PER-1) and (PER- 2) (38\%), and confers high-level resistance to Ceftazidime, Cefotaxime and Aztreonam [10].

\section{Aims of Study}

Molecular detection of bla genes OXA-4, OXA-10 and VEB-1 which responsible for extended-spectrum $\beta$ lactamase (ESBL) in multidrug resistant $P$. aeruginosa strains.

\section{Materials and Methods}

\section{Burn's Units Swabs Collection}

This study last for nine months starting from beginning of August 2012, till the end of April 2013. One hundred environmental swaps were collected from burn's units in three hospitals in Baghdad, Al-Kindi General Teaching Hospital / Rusafa (40 swabs), Al-Yarmuk General Teaching Hospital / Karkh (35 swabs) and Al-Imam Ali Hospital / Rusafa (25 swabs). The swabs collected from burn's units environment included (gloves, beds, floors, benches, walls and washing baths) in the mentioned three hospitals.

\section{Isolation and Identification of Bacteria}

All swabs obtained were cultured directly on MacConkey agar and Blood agar media and, incubated aerobically at $37^{\circ} \mathrm{C}$ for $24 \mathrm{hr}$ and citrimide agar at $42^{\circ} \mathrm{C}$. Identification by conventional biochemical methods and confirmed by API 20 E standardized identification system [11, 12]. Antimicrobial susceptibility test was conducted upon fifteen isolates of $P$. aeruginosa against 12 antibiotic was conducted by disc diffusions methods (DDM), as previously reported by Bauer, et al [13].

\section{DNA extraction}

Genomic DNA and Plasmid DNA were extracted from isolates of burn's units samples using 2 Mini Kits extraction Genomic DNA and Plasmid DNA, Purification depending on instruction of manufacturing company (Geneaid, Thailand).

\section{PCR detection of ESBLs genes}

Conventional PCR was used for the detection of ESBLs genes in $P$. aeruginosa isolated from burn's units (environmental isolates), which were (bla OXA-10), (bla OXA-4) and (bla VEB-1).

The primers sequence for ESBL genes are shown in Table (1).

Primer preparation: Lyophilized forward and reverse primers were suspended with suitable volume of TE buffer as recommended by Bioneer Corporation protocol. Lyophilized primers were dissolved in deionized water to give a final concentration of $(100 \mathrm{pM} / \mu \mathrm{l})$ (stock solution); to prepare $10 \mu \mathrm{M}$ concentration as work primer solution then $10 \mathrm{pM} / \mu \mathrm{l}$ was re-suspended in $90 \mu \mathrm{l}$ of deionized water to reach a final concentration of $10 \mu \mathrm{M}$.

Table (1): The sequence of forward and reverse primers of blaOXA-4, blaOXA-10 and blaVEB-1 genes.

\begin{tabular}{|c|c|c|c|}
\hline $\begin{array}{l}\text { Primer } \\
\text { Name }\end{array}$ & $5^{\prime}-\quad$ Sequence $-3^{\prime}$ & $\begin{array}{l}\text { Detected } \\
\text { gene }\end{array}$ & $\begin{array}{l}\text { Product } \\
\text { size }\end{array}$ \\
\hline OXA-4 & TCA ACA GAT ATC & & \\
\hline $\begin{array}{l}\text { (F) } \\
\text { OXA-4 }\end{array}$ & $\begin{array}{l}\text { TCT ACT GTT } \\
\text { TTT }\end{array}$ & $\underset{4}{b l a O X A-}$ & 216bp \\
\hline $\begin{array}{l}\text { OXA-4 } \\
\text { (R) }\end{array}$ & $\begin{array}{c}\text { TTT ATC CCA TTT } \\
\text { GAA TAT GGT }\end{array}$ & 4 & $200 \mathrm{P}$ \\
\hline OXA-10 & TCA ACA AAT CGC & & \\
\hline (F) & CAG AGA AG & blaOXA- & 277bp \\
\hline $\begin{array}{l}\text { OXA-10 } \\
\text { (R) }\end{array}$ & $\begin{array}{c}\text { TCC CAC ACC AGA } \\
\text { AAA ACC A }\end{array}$ & 10 & $27 / \mathrm{pp}$ \\
\hline VEB-1 & CGA CTT CCA TTT & & \\
\hline $\begin{array}{c}(\mathbf{F}) \\
\text { VEB-1 }\end{array}$ & $\begin{array}{c}\text { CCC GAT GC } \\
\text { GGA CTC TGC AAC }\end{array}$ & $\begin{array}{c}\text { blaVEB- } \\
1\end{array}$ & 643bp \\
\hline (R) & AAA TAC GC & & \\
\hline
\end{tabular}

The PCR mixtures were performed in a total volume of $20 \mu 1$ consisting of the followings : $15 \mu 1$ of distilled water, lyophilized of PCR master mix (Bioneer Corporation) was dissolved by vortexing, and $2 \mu 1$ of each primer forward and reverse (10 pM each), final $3 \mu$ l of DNA (total volume, 20 $\mu 1$ ) as illustrated in Table (2). 
Table (2): The mixture of conventional PCR working solution for detection of OXA-4, OXA-10 and VEB-1 genes in Pseudomonas aeruginosa.

\begin{tabular}{ccc} 
Component & Concentration & Volume $(\mu \mathrm{l})$ \\
\hline Deionizer water & - & 15 \\
Primer F. & 10 picomol & 1 \\
Primer R. & 10 picomol & 1 \\
DNA & $5-50$ ng & 3 \\
Total Volume & & $20 \mu \mathrm{l}$ \\
\hline
\end{tabular}

Amplification was included in every set of PCR reactions, the reaction mixtures following a "hot start" were subjected to empirically optimized thermal cycling program which represented in Tables (3, 4 and 5).

Table (3): PCR program for OXA-4 gene amplification by conventional methods.

\begin{tabular}{ccccc}
\hline No. & Steps & Temperature & Time & cycles \\
1. & Initial & $\left({ }^{\circ}\right)$ & 4 & 1 \\
Denaturation & Denaturation & 95 & $\mathbf{1}$ & \\
min & 1 & 30 \\
3. & Annealing & 94 & 1 & \\
Extension & Final & 51 & 5 & 1 \\
\hline
\end{tabular}

Table (4): PCR program for OXA-10 gene amplification by conventional methods.

\begin{tabular}{|c|c|c|c|c|}
\hline No. & Steps & $\begin{array}{c}\text { Temperature } \\
\left({ }^{\circ} \mathbf{C}\right)\end{array}$ & Time & cycles \\
\hline 1. & $\begin{array}{c}\text { Initial } \\
\text { Denaturation }\end{array}$ & 96 & $\begin{array}{c}5 \\
\min \end{array}$ & 1 \\
\hline 2. & Denaturation & 96 & $\begin{array}{l}30 \\
\text { sec }\end{array}$ & \\
\hline 3. & Annealing & $55,58,60$ & $\begin{array}{l}45 \\
\text { sec }\end{array}$ & 30 \\
\hline 4. & Extension & 72 & 1 & \\
\hline 5. & $\begin{array}{c}\text { Final } \\
\text { extension }\end{array}$ & 72 & $\begin{array}{c}5 \\
\min \end{array}$ & 1 \\
\hline
\end{tabular}

Table (5): PCR program for VEB-1 gene amplification by conventional methods.

\begin{tabular}{|c|c|c|c|c|}
\hline No. & Steps & $\begin{array}{c}\text { Temperature } \\
\left({ }^{\circ} \mathbf{C}\right)\end{array}$ & Time & cycles \\
\hline 1. & $\begin{array}{c}\text { Initial } \\
\text { Denaturation }\end{array}$ & 94 & $\begin{array}{c}5 \\
\min \end{array}$ & 1 \\
\hline 2. & Denaturation & 94 & $\begin{array}{l}45 \\
\text { sec }\end{array}$ & \\
\hline 3. & Annealing & $50-64$ & $\begin{array}{c}1 \\
\min \end{array}$ & 30 \\
\hline 4. & Extension & 72 & $\begin{array}{c}1 \\
\min \end{array}$ & \\
\hline 5. & $\begin{array}{c}\text { Final } \\
\text { extension }\end{array}$ & 72 & $\begin{array}{c}7 \\
\min \end{array}$ & 1 \\
\hline
\end{tabular}

\section{Results and Discussion}

The cultural result of 100 environmental swabs collected from burn's units (gloves, beds, floors, benches, walls and washing baths) of the three hospitals, revealed that $38(38 \%)$ of swabs gave positive result for bacterial growth and the rest $62(62 \%)$ were negative. The predominant bacteria was P. aeruginosa $15(39.50 \%)$, followed by Staphylococcus aureus 8 (21.0\%) while Klebsiella pneumonia came thirdly 6 (15.7\%), then Escherichia coli 3 (7.8\%), Pseudomonas putida, Enterobacteraerogenes recovered in similar percentage $2(5.26 \%)$, the least isolated microorganisms were Acinetobacterbaumannii and Proteus mirabilis as 1 (2.63\%) for each, as illustrated inTable-6. 
Gram negative organisms a client the highest incidence, $P$. aeruginosa was found to be the most common isolate followed by E.coli, and Klebsiella spp [14]. These organisms did not have fastidious growth requirements and can grow at various temperatures and $\mathrm{pH}$ conditions prevalent in the hospital environment, and in addition, were able to exploit varieties of carbon and energy sources. These properties explain the ability of these pathogens to persist for a reasonable time in either dry or moist conditions in the hospital environment, thereby causing disease. These hard line posture combined with their intrinsic resistance to many antimicrobial agents, contribute to the organisms fitness and enable them to spread in the hospital environment [15]. One of the most worrisome characteristics of $P$. aeruginosa is its low antibiotic susceptibility, which is attributable to a concerted action of multidrug. Pseudomonas aeruginosa is naturally resistant to a large range of antibiotics and may demonstrate additional resistance after unsuccessful treatment, also it has ESBLs enzymes that mediate resistance to extended-spectrum (third generation) cephalosporins (ceftazidime, cefotaxime, and ceftriaxone) and Monobactam (Aztreonam) but did not affect Carbapenems (meropenem or imipenem), [16].

Table (6): Types of environmental isolates from burn's units.

\begin{tabular}{lcccc}
\hline \multicolumn{1}{c}{ Isolate } & \multicolumn{2}{c}{$\begin{array}{c}\text { Number \& } \\
\text { frequency }\end{array}$} & $\begin{array}{c}\text { Total } \\
\text { So. }\end{array}$ & $\begin{array}{c}\text { Percentage } \\
(\%)\end{array}$ \\
& $\begin{array}{c}\text { Single } \\
\text { Isolates }\end{array}$ & $\begin{array}{c}\text { Mixed } \\
\text { Isolates }\end{array}$ & & \\
\hline Pseudomonas & 11 & 4 & 15 & 39.50 \\
aeruginosa & & & & 21.0 \\
Staphylococcus aureus & 6 & 2 & 8 & 15.7 \\
Klebsiella pneumonia & 4 & 2 & 6 & 7.8 \\
Escherichia coli & 3 & - & 3 & 5.26 \\
Pseudomonas putida & 2 & - & 2 & 5.26 \\
Enterobacteraerogenes & 2 & - & 2 & 2.63 \\
Acinetobacterbaumannii & 1 & - & 1 & $\mathbf{2 . 6 3}$ \\
Proteus mirabilis & - & 1 & 1 & 100 \\
$\quad$ Total No. & 29 & 9 & 38 &
\end{tabular}

Antimicrobial susceptibility was performed on 15 P. aeruginosa isolates against 12 antibiotics; 7 of them were ESBLs represented by Cefotaxime, Ceftriaxone, Ceftazidime, Imipenem, Aztreonam, Piperacillin and Cefepime, and to 5 antibiotics were non ESBLs represented by Aminoglycoside (Amikacin, Gentamicin and Tobramycin), Chloramphenicol and Fluoroquinolone (Ciprofloxacin), by DDM [13]. The antibiogram for studied isolates was revealed that all isolates $100 \%$ resist to Ceftrixone, Cefepime, Chloramphenicol and Tobramycin,and this resistance became 93.3 against Gentamicin, while 86.6 against each Cefotaxime and Ceftazidime, followed by $80 \%$ for Piperacillin, and lower resistance $60 \%$ for Aztreonam, Amikacin respectively and $46.5 \%$ for Ciprofloxacin. Pseudomonas aeruginosa are becoming resistant to commonly used antibiotics and gaining more and more resistance to newer antibiotics [17]. This study found that Imipenem is the drug of choice in treatment of $P$. aeruginosa, because $66.6 \%$ of isolates were susceptible to it and only five isolate were exhibit resistance, Table (7) represent these results.

Table (7): Antibiotic susceptibility of Pseudomonas aeruginosa isolates.

\begin{tabular}{|c|c|c|c|c|c|}
\hline \multirow{2}{*}{ Antibiotics } & \multirow{2}{*}{$\begin{array}{c}\text { Disk } \\
\text { content }\end{array}$} & \multicolumn{2}{|c|}{ Resistant } & \multicolumn{2}{|r|}{ Intermediate } \\
\hline & & No. & $\%$ & No. & $\%$ \\
\hline Cefotaxime & $30 \mu \mathrm{g}$ & 13 & 86.6 & - & - \\
\hline Ceftrixone & $30 \mu \mathrm{g}$ & 15 & 100.0 & - & - \\
\hline Ceftazidime & $30 \mu \mathrm{g}$ & 13 & 86.6 & 1 & 6.6 \\
\hline Imipenem & $10 \mu \mathrm{g}$ & 5 & 33.3 & - & - \\
\hline Aztreonam & $30 \mu \mathrm{g}$ & 9 & 60 & - & - \\
\hline Amikacin & $30 \mu \mathrm{g}$ & 9 & 60 & 1 & 6.6 \\
\hline Gentamicin & $10 \mu \mathrm{g}$ & 14 & 93.3 & - & - \\
\hline Ciprofloxacin & $5 \mu \mathrm{g}$ & 6 & 40 & - & - \\
\hline Piperacillin & $100 \mu \mathrm{g}$ & 12 & 80 & 1 & 6.6 \\
\hline Cefepime & $30 \mu \mathrm{g}$ & 15 & 100.0 & - & - \\
\hline Chloramphenicol & $30 \mu \mathrm{g}$ & 15 & 100.0 & - & - \\
\hline Tobramycin & $10 \mu \mathrm{g}$ & 15 & 100.0 & - & - \\
\hline
\end{tabular}

Sensitive
$\%$
13.3
-
6.6
66.6
40
33.3
6.6
60
13.3
-
-
-

The outcome of PCR amplification of ESBLs (bla) genes in the hospital environment clarified that $P$. aeruginosa noticed in almost all fifteen $(39.50 \%)$ isolates were ESBLs producer. The bla OXA-10 gene was detected in all 
isolates $15(100 \%)$ Figure (1), and in Figure (2), only $6(40 \%)$ were positive for blaVEB-1 gene. While only one (6.6\%) isolate was positive for OXA-4 ESBLs as shown in Figure (3), and Table (8). The structure of the $P$. aeruginosa genome is a mosaic to be the result of multiple acquisitions from different donors during its evolution, to horizontal gene transfer includes the presence of genes or remnants of genes associated with mobile elements (i.e., insertion sequences, bacteriophages or plasmids) and the presence of numerous genomic islands [18]. There is no phenotypic confirmatory method for the presence of OXA gene and VEB-1 in P. aeruginosa, the current study provides precise and the only reliable genotypic method for detecting OXA, VEB resistance genes in $P$. aeruginosa. In a similar study conducted by Bert et al. [19], they reported that PCR detecting OXA-10 gene in $P$. aeruginosa isolates was positive in $68(26.3 \%)$ isolates; 31 carried blaOXA-10, one carried blaOXA-14 and 36 carried a new variant intermediate between blaOXA-13 and blaOXA-19, levels of antimicrobial susceptibility and mechanisms of resistance to anti pseudomonal agents of P.aeruginosa were evaluated by a European team, [20] who showed close results to our study except for Impinem.

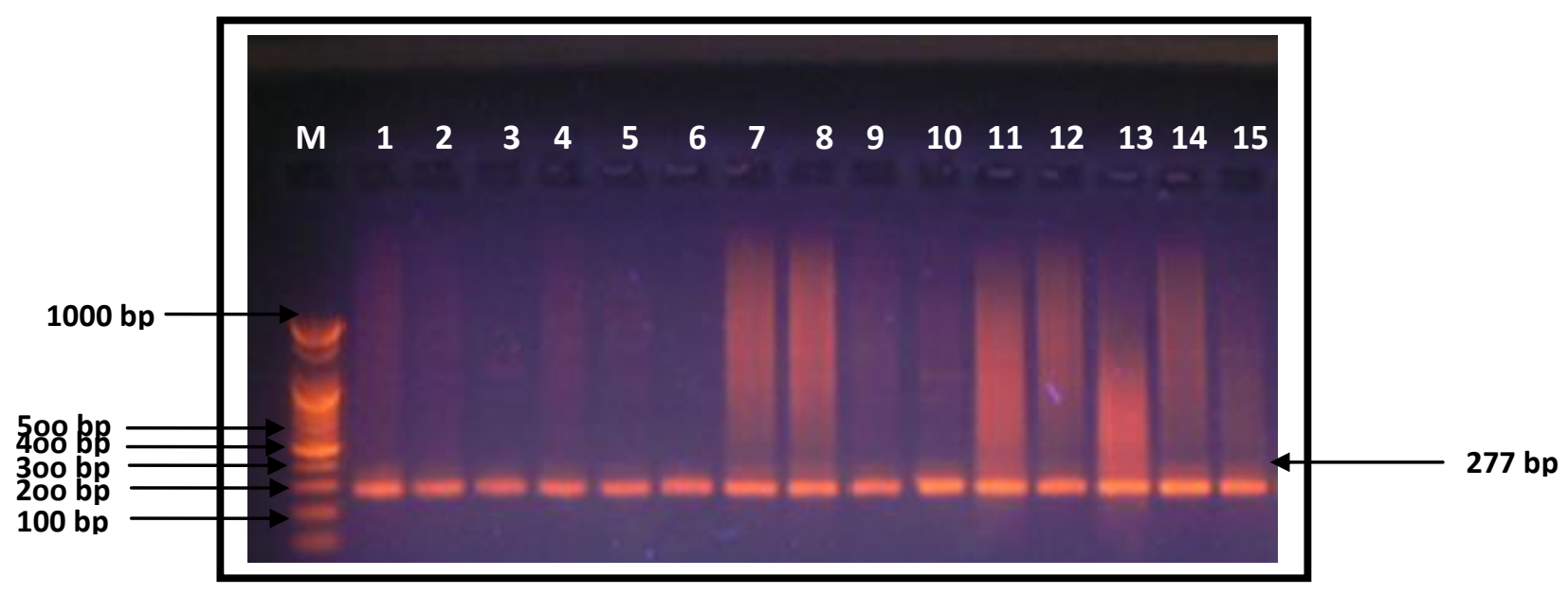

Fig. (1): Agarose Gel electrophoresis of PCR product for the detection of ESBL blaOXA-10 gene (277bp) using $1 \%$ agarose for 90 min at 70 volt , stained with ethidium bromide, M: Marker DNA ladder Size (1000bp); Lanes 1-15 positive for blaOXA-10 (277 bp)

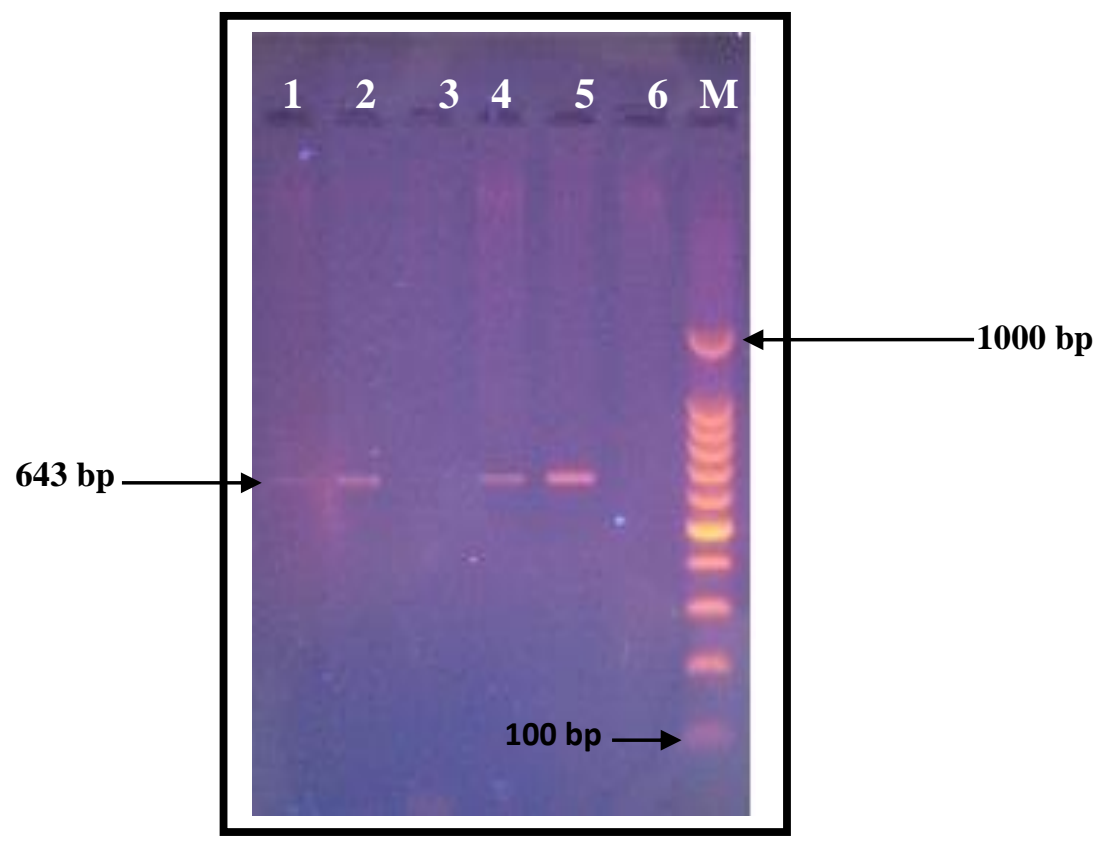

Fig. (2): Agarose Gel electrophoresis of PCR product for detection of ESBL blaVEB-1 gene (643bp) using $1 \%$ agarose for 90 min at 70 volt, stained with ethidium bromide, M: Marker DNA lader

Size (1000bp) ; Lanes 1,2,4,5 positive for blaVEB-1 (643 bp). 


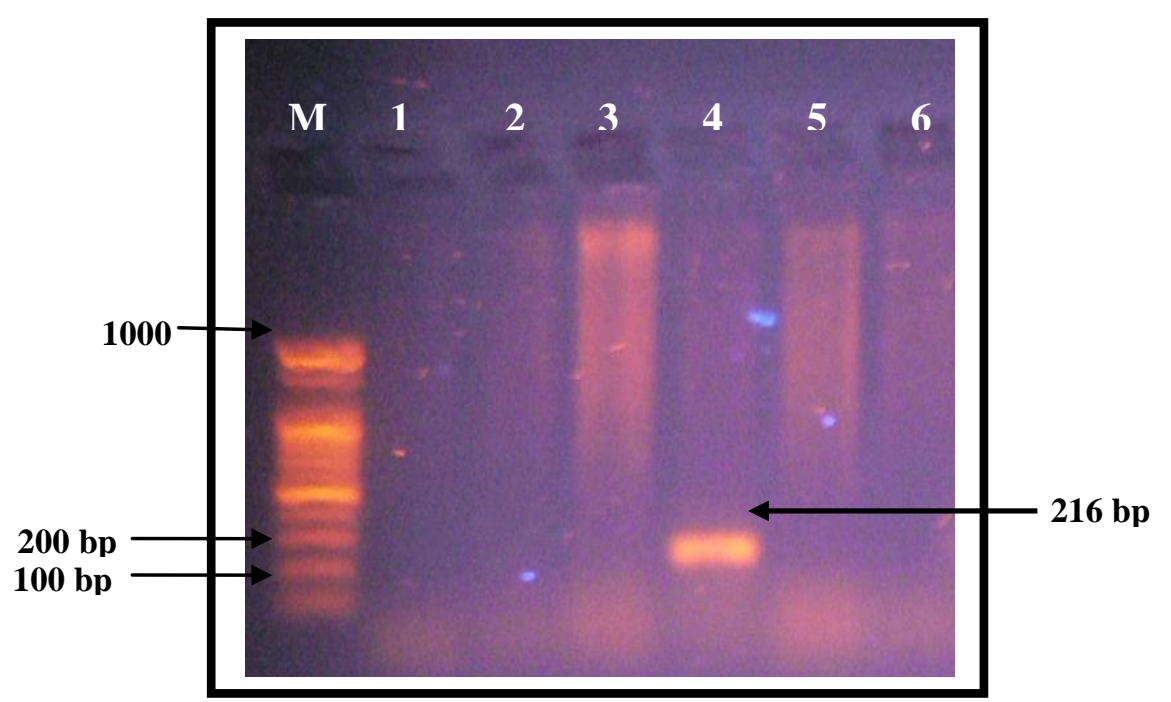

Fig. (3): Agarose Gel electrophoresis of PCR product for detection of ESBL blaOXA-4 gene (216bp) using $1 \%$ agarose for 90 min at 70 volt, stained with ethidium bromide, M: Marker DNA lader Size (100bp); Lanes (4) positive for bla OXA-4 (216 bp).

Table (8): Distribution of bla genes in environmental $P$. aeruginosa isolates

\begin{tabular}{|c|c|c|c|c|c|c|c|}
\hline \multirow{2}{*}{$\begin{array}{c}\text { Sam } \\
\text { ples } \\
\text { Coll } \\
\text { ecte } \\
\text { d }\end{array}$} & \multirow{2}{*}{ 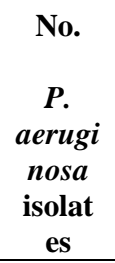 } & \multicolumn{2}{|c|}{ blaOXA-10 (277 bp) } & \multicolumn{2}{|c|}{$\begin{array}{c}\text { blaOXA-4 (216 } \\
\text { bp) }\end{array}$} & \multicolumn{2}{|c|}{ bla VEB-1(643bp) } \\
\hline & & $\begin{array}{l}\text { Positi } \\
\text { ve }\end{array}$ & $\begin{array}{l}\text { Neg } \\
\text { ative }\end{array}$ & $\begin{array}{l}P \\
\text { os } \\
\text { iti } \\
\text { ve }\end{array}$ & $\begin{array}{l}\text { Neg } \\
\text { ative }\end{array}$ & $\begin{array}{l}\text { Posit } \\
\text { ive }\end{array}$ & Negative \\
\hline $\begin{array}{l}\text { Burn's } \\
\text { Units }\end{array}$ & 15 & $\begin{array}{c}15 \\
100 \%\end{array}$ & $\begin{array}{c}0 \\
0.0 \%\end{array}$ & $\begin{array}{c}1 \\
6.6 \\
\%\end{array}$ & $\begin{array}{c}14 \\
93.3 \\
\%\end{array}$ & $\begin{array}{c}6 \\
40 \%\end{array}$ & $\begin{array}{c}9 \\
60 \%\end{array}$ \\
\hline
\end{tabular}

Six isolates from total 15 carried more than one kind of gene on their plasmids, one isolate hold triple genes (blaOXA-10, blaOXA-4 and VEB-1), five isolates carried two gene with different kind of frequency for each genes, and 9 isolates carried only one gene blaOXA-10 as demonstrated inTable (9).

Table (9): Distribution of resistance ESBLs (bla) genes in environmental isolates.

\begin{tabular}{cccc}
\hline $\begin{array}{c}\text { No. } \\
\text { P. aruginosa }\end{array}$ & OXA-10 & OXA-4 & VEB-1 \\
Isolates & Positive & Positive & Positive \\
1. E.I. & + & & + \\
2. E.I. & + & + \\
3. E.I. & + & \\
4. E.I. & + & \\
5. E.I. & + & & \\
6. E.I. & + & & \\
7. E.I. & + & & \\
8. E.I. & + & \\
9. E.I. & + & + \\
10. E.I. & + & & + \\
11. E.I. & + & & + \\
12. E.I. & + & & + \\
13. E.I. & + & & \\
14. E.I. & + & & \\
15. E.I. & + & & $+(+)$ \\
\hline Total $(15)$ & $15(+)$ & & \\
Isolate from & & & \\
Burn's Units & & & \\
\hline
\end{tabular}


In the current study, testing for ESBLs production using antibiotics agents isolates resistance and molecular detection of OXA-10, OXA-4 and VEB-1 genes in $P$. aeruginosa isolates revealed that there is a harmony between result of antibiotic resistance and positive molecular detection of these genes.

\section{References}

1. Branson, R., Eichhorn, J., Frantz, I., Mininni, N. and Overdyk, F. (2010). "Clinical alarms and the impact on patient safety. Initiatives- patient safety- Organization”. Pp. 1-8.

2. Kramer, A., Scwebke, I. and Kampf, G. (2006). "How long do nosocomial pathogens persist on inanimate surfaces". A systematic review. BMC Infect Dis. 6:130.

3. Tavajjohi, Z., Moniri, R. and Khorshidi, A. (2011). "Detection and characterization of resistance and extended spectrum $\beta$-lactamase producing (ESBL) Pseudomonas aeruginosa isolates in a teaching hospital". African J. Microbiol Res. 5(20): 3223-28.

4. Peirano, G. and Pitout, J. (2010). "Molecular epidemiology of Escherichia coli producing CTX-M a Lactamases : worldwide emergence of clone ST131 025:H4". Internat J. of Antimicrob. Agents. 35: 316-321.

5. Ramphal, R. and Ambrose, P. (2006). "Extended-spectrum b-lactamases and clinical outcomes: Current Data". Clin. Infect. Dis. 42:S164-72.

6. Bush, K., Jacoby, G. and Medeiros, A. (1995). "A functional classification scheme for beta-lactamases and its correlation with molecular structure". Antimicrob. Agents Chem. 1995; 39:1211-33.

7. Wikipedia, (2010). Beta-lactamase. Accessed on December 10, 2010.

8. Ashraf, E., Iman, E. and Shoroukm, K. (2008). "OXA-type- beta-lactamases among extended-spectrumcephalosporin non-susceptible Pseudomonas aeruginosa isolates collected from a large teaching hospital in Cairo". Egypt J. of Med. Microbiol. 17(4): 565-572.

9. Mirsalehian, A., Feizabadi, M., Nakhjavani, F., Jabalameli, F., Goli, H. and Kalantari, N. (2010). "Detection of VEB-1, OXA-10 and PER-1 genotypes in extended-spectrum beta-lactamase-producing Pseudomonas aeruginosa strains isolated from burn patients". Burns. 36: 70-74.

10. Aktaş, Z., Poirel, L., Şalcıglu, M., Ozcan, P., Midilli, K. and Bal, C. (2005). "PER-1- and OXA-10-like blactamase in ceftazidime resistant Pseudomonas aeruginosa isolates from intensive care unit patients in Istanbul". Turkey Clin. Microbiol. Infect. 11: 193-198.

11. Forbes, B., Sahm, D. and Weissfeld, A. (2007). Bailey and Scott's Diagnostic Microbiology .International $12^{\text {th }}$ Edition, Mosby, U.S.A.

12. Jawetz, E., Melnick, J. and Adelberg, E. (2007). Med Microbial.(24 ${ }^{\text {nd }}$ ed.). Appleton and Lange USA.Pp263-288.

13. Bauer, A., Kirby, W., Sherris, J. and Turck, M. (1966).Antibiotic susceptibility testing by a standardized single disk method.Am J ClinPathol.45(4):493-496.

14. Church, D., Elsayed, S., Reid, O., Winston, B. and Lindsay, R. (2006). Burn wound infections. ClinMicrobiol 1 Rev.19(2): 403-34.

15. El-Mahmood, A, Alo, N. and Alo, A. (2010). Susceptibility of nosocomial Staphylococcus aureus, Esherichia coli and Candida albicansto some antimicrobial drugs routinely used in Adamawa State Hospitals, Nigeria. J. Clin. Med. Res. 2(8): 125-134.

16. Lee, S., Park, Y., Kim, M., Lee, H., Han, K., Kang, C. and Kang, M. (2005). Prevalence of Ambler class A and D beta-lactamase among clinical isolates of Pseudomonas aeruginosa in Korea. J. Antimicrob. Chemother. 56:122127.

17. Rajat, R., Ninama, G., Mistry, K., Parmar, R., Patel, K. and Vegad, M. (2012). Antibiotic resistance pattern in Pseudomonas aeruginosa species isolated at a tertiary care hospital, Ahmadabad. Nati J. of Med. Rec. 2(2): 156159.

18. Kulasekara, B and Lory, S. (2004).The Genome of Pseudomonas aeruginosa.In Pseudomonas: Volume 1 Genomics, Lifestyle and Molecular Architecture. Ramos JL (ed). New York: Kluwer Academic/Plenum Publishers. $47-76$.

19. Bert, F., Branger, C. and Zechovsky, N. (2002). "Identification of PSE and OXA- $b$-lactamase genes in Pseudomonas aeruginosa using PCR-restriction fragment length polymorphism". J. of Antimicrobial. Chem. 50(3): 11-8.

20. Strateva, T., Ouzounova-Raykova, V., Markova, B., Todorova, A., Marteva-Proevska, Y. and Mitov, I. (2007). "Problematic clinical isolates of Pseudomonas aeruginosa from the university hospitals in Sofia, Bulgaria: current status of antimicrobial resistance and prevailing resistance mechanisms". J. of Med. Microbiol. 56(7): 956-963. 